\title{
BIOTERRORISM: THE DEVELOPMENT AND ITS REGULATIONS ACCORDING TO THE INTERNATIONAL LAW
}

\author{
Yaksa Elyasa \\ Lampung Sweeping Community, Indonesia, Email: yaksaelyasa@gmail.com
}

Submitted: August 18, 2020; Reviewed: January 7, 2021; Accepted: February 9, 2021

\begin{tabular}{ll}
\hline \multicolumn{1}{c}{ Article Info } & \multicolumn{1}{c}{ Abstract } \\
\hline $\begin{array}{l}\text { Keywords: } \\
\text { Terrorism, Bioterrorism, }\end{array}$ & The biological weapon used as a terrorism facility \\
International Law & (bioterrorism) could endanger the lives of mankind. Besides \\
& its purpose of mass destruction, this weapon has been banned \\
& from being used towards the human. Bioterrorism threat at \\
DOI: & least had occurred in more than 30 countries across the globe. \\
10.25041/lajil.v3i1.2103 & In the 14 ${ }^{\text {th }}$ century, bioterror incidents recorded in black death \\
& plagues in Europe caused more than 50 million deaths and \\
& vanished more than 60\% of its population back then. Because \\
& of the bioweapon impacts, there are concerns if this weapon \\
& is under irresponsible parties such as the group of terrorists. \\
& Several regulations on the prohibition of biological weapons \\
& have been made, such as the Production and Stockpiling of \\
& Bacteriological [Biological] and Toxin Weapons and Their \\
& Destruction 1972 (Biological Weapon Convention 1972). \\
& However, it seems that they have not solved using biological \\
& weapons as a means of terrorism. The purpose of this paper is \\
& to find out how international law arrangements regarding \\
& bioterrorism. This research used normative legal research \\
with secondary data sources and literature study techniques.
\end{tabular}

\section{A. Introduction}

Terrorism is a crime that is generally based on ideological, political, and historical motives, and it is also a part of global and regional problems. ${ }^{1}$ Since thousands of years ago, humans have used terror used against the regime born since the existence of power. In the first century, the group 'Sicarii' (Jews), with its Zealot movement, had carried out one tactic with guerrilla warfare to fight against Roman rulers with terror. ${ }^{2}$ Terrorists implement a variety of weapons, not only conventional ones but also weapons of mass destruction, for example, biological weapons, to do bioterrorism. Since early times, states and terror groups have had the desire and ability to develop the most dangerous pathogens used as biological weapons. ${ }^{3}$ Bioterrorism is

\footnotetext{
1 Muhammad A. S. Hikam, Deradikalisasi: Peran Masyarakat Sipil Indonesia Membendung Radikalisme, (Jakarta: Kompas Media Nusantara, 2016), 33-34.

${ }^{2}$ Adjie S, Terorisme, (Jakarta: Pustaka Sinar Harapan, 2005), 1.

3 Divashree Sharma, Ambrish Mishra, Vilas Newaskar, Ankit Khasgiwala, "BIOTERRORISM: LAW ENFORCEMENT, PUBLIC HEALTH \& ROLE OF ORAL AND MAXILLOFACIAL SURGEON IN EMERGENCY PREPAREDNESS", Journal of Oral and Maxillofacial Surgery 15, no. 2 (2016): 137-143, 137, DOI: $10.1007 / \mathrm{s} 12663-015-0834-\mathrm{x}$.
} 
the intentional release of viruses, bacteria, and toxins to create certain diseases that targeted a population to achieve the goals requested by terrorists, creating terror to society. ${ }^{4}$ Bioterrorism attacks affect not only humans but also animals, plants, and the environment as well. ${ }^{5}$ Some bioterrorism incidents had occurred, for example:

Chart 1.1

The Case of Bioterrorism

\begin{tabular}{|c|c|c|c|c|}
\hline No & Case & Time/Place & Victim & Information \\
\hline 1 & $\begin{array}{l}\text { The Black } \\
\text { sea Bubonic } \\
\text { Plague }\end{array}$ & $\begin{array}{l}13^{\text {th }} \text { Century/ } \\
\text { Kaffa (Today } \\
\text { Known as } \\
\text { Krimea, } \\
\text { Ukraine) }\end{array}$ & Not known & $\begin{array}{l}\text { This attack was carried out by tartar } \\
\text { forces while attacking Genoese forces } \\
\text { in Kaffa, the black sea. Tartar troops } \\
\text { were affected by the bubonic plague } \\
\text { and caused many of the soldiers to die. } \\
\text { Then the tartar forces, with their } \\
\text { ingenuity, changed the situation by } \\
\text { attacking the Genoa troops and } \\
\text { throwing the dead bodies caused by the } \\
\text { plague into the siege to repel the troops } \\
\text { out of the city. }\end{array}$ \\
\hline 2 & RISE & $\begin{array}{l}\text { 1972/ } \\
\text { Chicago, } \\
\text { United States } \\
\text { of America }\end{array}$ & $\begin{array}{l}\text { No victim/ } \\
\text { Successfully } \\
\text { thwarted by } \\
\text { local } \\
\text { authorities }\end{array}$ & $\begin{array}{l}\text { In } 1972 \text { police arrested two college } \\
\text { students in Chicago, Allen Charles } \\
\text { Schwander and Stephen Pera. They } \\
\text { belonged to the terrorist organization } \\
\text { called RISE that was established in } \\
1971 .^{7} \text { RISE was on the verge of } \\
\text { releasing typhoid and other bacteria to } \\
\text { poisoning Chicago the water supply } \\
\text { system, to commit mass murder. }\end{array}$ \\
\hline 3 & Rajneeshee & $\begin{array}{l}\text { 1984/ } \\
\text { Oregon, } \\
\text { United States } \\
\text { of America }\end{array}$ & $\begin{array}{l}751 \text { were } \\
\text { Injured }\end{array}$ & $\begin{array}{l}\text { In } 1984 \text { in Dallas, Oregon, a group of } \\
\text { Bhagwan Shree Rajneesh's followers } \\
\text { was poisoning the food through the } \\
\text { deliberate contamination of salad bars } \\
\text { at ten local restaurants with Salmonella } \\
\text { Typhimurium. It sickened } 751 \text { people } \\
\text { back then, and It is known that they did } \\
\text { such an act because the cult tried to } \\
\text { manipulate the result of the } 1984 \\
\text { election. }\end{array}$ \\
\hline
\end{tabular}

\footnotetext{
${ }^{4}$ Nur Farida, Me And Global Environment (Jakarta: Grasindo, 2009), 119.

${ }^{5}$ Mahendra Pal, Meron Tsegaye, Fikru Girzaw, Hailegebrael Bedada, Vikram Godishala, Venkataramana Kandi, "AN OVERVIEW ON BIOLOGICAL WEAPONS AND BIOTERRORISM", American Journal of Biomedical Research 5, no. 2 (2017): 24-34, 24, DOI: 10.12691/ajbr-5-2-2.

${ }^{6}$ Robert S. Gottfried, The Black Death: Natural And Human Disaster In Medieval Europe (New York: The Free Press, 1985), 37.

${ }^{7}$ George Michael, Lone Wolf Terror and the Rise of Leaderless Resistance (Nashville: Venderbilt University Press, 2012), 65 .

8 https://www.nytimes.com/1972/01/19/archives/2-youths-charged-with-plot-to-poison-water-of-chicago.html accessed on December 16, 2019.

${ }^{9}$ W. Seth Carus, "THE THREAT OF BIOTERRORISM", National Defense University Institute for National Strategic Studies 127, (1997): 1-4, 2.
} 


\begin{tabular}{|c|c|c|c|c|}
\hline 4 & $\begin{array}{l}\text { Aum } \\
\text { Shinrikyo }\end{array}$ & $\begin{array}{l}\text { 1995/ Tokyo, } \\
\text { Japan }\end{array}$ & $\begin{array}{l}13 \text { dead dan } \\
\text { thousands } \\
\text { were injured }\end{array}$ & $\begin{array}{l}\text { in } 1995 \text { a japan based religious cult } \\
\text { Aum Shinrikyo committed spread sarin } \\
\text { nerve gas, a chemical agent, on the } \\
\text { Tokyo subway. The cult is also known } \\
\text { to be capable of producing biological } \\
\text { agents and tried to use them. } \\
\text { Police investigations suggest that the } \\
\text { cult has among its members' skilled } \\
\text { scientists and technicians trained and } \\
\text { experienced in microbiology, who } \\
\text { attempted to make weapons using } \\
\text { anthrax, botulinum toxin, Q-fever, and } \\
\text { even ebola. }{ }^{10}\end{array}$ \\
\hline 5 & $\begin{array}{l}\text { Anthrax } \\
\text { Packages }\end{array}$ & $\begin{array}{l}\text { 2001/ United } \\
\text { States of } \\
\text { America }\end{array}$ & $\begin{array}{l}\text { More than } \\
30.000 \\
\text { people were } \\
\text { infected, } \\
\text { five people } \\
\text { died, and } 17 \\
\text { were } \\
\text { injured. }\end{array}$ & $\begin{array}{l}\text { One week after the terrorist attack on } \\
\text { the World Trade Center building, } \\
\text { America was attacked by an envelope } \\
\text { filled with anthrax spores sent to } \\
\text { government offices and media } \\
\text { companies throughout the country. }{ }^{11}\end{array}$ \\
\hline
\end{tabular}

Bioterrorism is not a new thing. At least hundreds of bioterrorism incidents have occurred in more than 30 countries around the world. ${ }^{12}$ Biological weapons as weapons of mass destruction are classified as hazardous weapons because of their nature. This type of weapon can kill millions of civilians, jeopardize the natural environment and destroy future generations through their catastrophic effects. ${ }^{13}$ According to Dr. Connie Rahakundini Bakrie, military and defence observers from the University of Indonesia said that biological weapons are a popular tool because they are cheap and effective. For example, the use of one gram botulinus would kill 10,000,000 (ten million) people. Botulinus is a rare poisoning caused by a poison from the colostridium botulinum. Botulism is considered 3,000,000 (three million) times stronger than the best chemical weapons nowadays. In comparison, the cost for the effectiveness of an attack on 1 square kilometre is 2000 US dollars on conventional weapons, 800 US dollars on nuclear weapons, and 1 US dollar on biological weapons. ${ }^{14}$ Because of that, biological weapons are also referred to as "poor man's" nuclear bomb. ${ }^{15}$

International law has set several provisions concerning the use of biological weapons such as the 1925 Geneva Protocol and the Convention on the Prohibition of Development, Production and Stockpiling of Bacteriological (Biological) and Toxin Weapons and on Their

\footnotetext{
${ }^{10} \mathrm{Ibid}$.

${ }^{11}$ Cameron Funk, "AMERICA'S STATE OF READINESS AGAINST BIOTERRORISM ", Pepperdine Policy Review 10, no. 1 (2018): 1-20, 1.

12 Revaz Beshidze, "WEAPONS OF MASS DESTRUCTION AND INTERNATIONAL TERRORISM", Georgia: Final Project Report, (2007): 1-36, 4.

13 Isna Rasdianah Aziz and Andika Saputra, "BIOTERRORISM: THE ROLE OF GENETICS AND MOLECULAR BIOLOGY”, Prosiding Seminar Nasional Biology for Life 3, no. 1 (2017): 63-69, 63, DOI: 10.24252/PSB.v3i1.5587.

${ }^{14}$ https://independensi.com/2020/03/24/covid-19-perang-biologi-berlakukan-darurat-militer/ accessed on March 27, 2020.

${ }^{15}$ Saira Gori1 \& Anjani Singh Tomar, "BIOTERRORISM \& BIODEFENSE: AN ENVIRONMENTAL AND PUBLIC HEALTH PREPAREDNESS", Rupkatha Journal on Interdisciplinary Studies in Humanities 12, no. 1 (2020): 1-15, 1, DOI: 10.21659/rupkatha.v12n2.13.
} 
Destruction (known as "Biological \& Toxin Weapon Convention" or BTWC) 1972. The Provisions of the Geneva Protocol 1925 clearly regulates the prohibition on the use of biological weapons. However, the protocol does not mention the prohibition of producing biological weapons by both the state and individuals. Simultaneously, the 1972 BTWC convention regulates the prohibition of the production, development, stockpiling of biological weapons and poisons in unjustified quantities and only for peaceful purposes. The BTWC CoAt least 183 countries $^{16}$, But it cannot be denied that many countries possess and develop biological weapons. Several countries still have had or are currently suspected of having biological weapons programs, including Argentina, Brazil, Canada, China, Cuba, Egypt, France, Germany, India, Iran, Iraq, Israel, Laos, Libya, North Korea, Pakistan, Russia, South Africa, Syria, Taiwan, the United Kingdom, and the United States, etc. ${ }^{17}$

Countries' ability to develop biological weapons has increased. It raises concerns about the possibility that terrorist groups will gain a transfer of biological weapon expertise to create bioterrorism through support from countries with such capacity. ${ }^{18}$ The country's noncompliance with the convention also raises concerns that biological weapons will fall into the wrong hands. On the other hand, terrorist groups and individuals with certain objectives increasingly show an interest in this type of weapon to causing mass fatalities. ${ }^{19}$ Public information openness also impacts the spreading of bioterrorism. According to Dr. Richard Clutterback, ${ }^{20}$ Many experts in the study of terrorism predict the likelihood of terrorists using biological and chemical as one of the prospects of terrorism itself. Methods for making nerve gas and biological pathogens easy to learn in recent decades. In actual fact, making sarin can be learned on the internet. Likewise, biological and chemical materials are easy to obtain and cheap and easy to learn anywhere. ${ }^{21}$ Therefore, this study aims to examine how international law regulations on combatting bioterrorism. This study's approach method is normative legal research with secondary data sources and literature study techniques.

\section{B. Discussion and Analysis}

Discussion and analysis will further explain and describe 2 (two) main issues: the development of bioterrorism and how international law regulates bioterrorism.

\section{The Develepoment of Bioterorisme}

Historically, the development of biological weapons has long been known to mankind. Early 14th century BC, the use of infectious diseases and other biological weapons was recognized. ${ }^{22}$ The first people documented using biological weapons are the hitties. They weaken their enemies by sending rams (possibly infected with tularemia). In the 4th century BC, the Greek historian Herodotus relates that archers of the sktihia used to infect their arrows by dipping them in a mixture of decomposed corpses and human blood. According to modern

\footnotetext{
${ }^{16}$ have ratified the BTWC Convention of the Biological Weapons Convention - United Nations Office at Geneva.

${ }^{17}$ W. Seth Carus, "A CENTURY OF BIOLOGICAL-WEAPONS PROGRAMS (1915-2015): REVIEWING THE EVIDENCE", The Nonproliferation Review Special Section: Nuclear Asia 24, no. 1-2 (2017): 129-153, 138, DOI: 10.1080/10736700.2017.1385765.

${ }^{18}$ Heather A. Dagen, “BIOTERRORISM: PERFECTLY LEGAL”, Catholic University Law Review 49, no. 2 (2002): 535-573, 536 .

${ }^{19}$ Ibid.

${ }^{20}$ Richard Clutterbuck, Terrorism in an Unstable World (London: Routledge, 2006), 6.

21 Ibid.

${ }^{22}$ Dennis D. Yakubu and Daniel A. Paul, "BIOLOGICAL WEAPONS A GLOBAL THREAT: A SUSTAINABLE APPROACH FOR EARLY IDENTIFICATION", African Journal of Environment and Natural Science Research 2, no. 2 (2019): 6-11, 6.
} 
world interpretations, the mixture might contained Colostridium perfingens and Colostridium tetani, as well as snake venom. ${ }^{23}$

\section{Chart 1.2}

The use of biological weapons before the era of microbiology

\begin{tabular}{|l|l|}
\hline Year & Event \\
\hline $14^{\text {th }}$ Century BC & $\begin{array}{l}\text { The Hittites sent infected rams to the enemy to weaken them. } \\
\text { According to Herodotus, the Skithians used to poison their } \\
\text { arrows with decomposed corpses. } \\
\text { Frederick Barbarossa, the holy Roman emperor, poisoned } \\
\text { water well with human corpses in Tortona, Italy. } \\
\text { The Mongols threw the bodies of plague victims into the city } \\
\text { of Kaffa. } \\
\text { Lithuanian army throws the manure into the town of } \\
\text { Carolstein (Bohemia) made from invected victims. } \\
\text { The Spanish mixed wine with the blood of lepers to sell to } \\
\text { their French enemies. } \\
\text { The Polish army shoots the saliva of rabid dogs to their } \\
\text { enemies. } \\
\text { Russian army hurls plague cadavers over the Swedish troops } \\
\text { in Reval (Estonia). } \\
\text { British officers distributed blankets from smallpox hospitals } \\
\text { to Native Americans. } \\
\text { Napoleon troops flooded the land around Mantua (Italy) to } \\
\text { increase the spread of malaria to the enemy } \\
\text { during the American civil war, the confederate sell clothes } \\
\text { used by people with yellow fever and smallpox to Union } \\
\text { Troops. }\end{array}$ \\
17650 & 1763
\end{tabular}

Source: V. Barras and G. greub, history of biological warfare and bioterrorism, journal of clinical and microbiology infection, Volume 20, Issue 06, 2014, p. 498.

The development of modern biological weapons began in the late $19^{\text {th }}$ century based on the science of microbiology initiated by Louis Pasteur and Robert Koch and their followers. ${ }^{24}$ They began to identify and control many biological agents that live in humans and animals, they also allowed scientists to produce certain pathogens on a large scale. In most cases, at least theoretically controlling their dissemination. After decades, this mindset does not seems to have been used as a new way to threaten or terrorize humans. ${ }^{25}$

Modern biological warfare began by countries involved in World War I, especially Germany and France (on a limited scale), who have developed secret biological weapons, such as the infections of animal feed with the bacillus anthracis and Burkholderia mallei to infect enemies. Whatever the impact of this biological weapons program might have been, for the first time in the history of chemical warfare and biological weapons, it has become a major political concern at the international level. As a result, the Geneva Protocol that bans the use of toxic

\footnotetext{
${ }^{23}$ V. Barras and G. greub, "HISTORY OF BIOLOGICAL WARFARE AND BIOTERRORISM", Journal of Clinical and Microbiology Infection 20, no. 06 (2014): 497-502, 498, DOI: 10.1111/1469-0691.12706.

24 Beth Ann Fiedler and Dmitry Nikolaenko, "INVESTIGATING COVID-19: RECURRING METHODOLOGICAL PROBLEMS IN THE STUDY OF INFECTIOUS DISEASE", Environmental Epidemiology 14, no. 2 (2020): 4-12, 2.

${ }^{25}$ V. Barras, et.al., Op.Cit., 499.
} 
gases and bacteriological methods in warfare in 1925 was ratified. ${ }^{26}$ The main concern regarding the use of biological weapons in the contemporary period then turned to use biological weapons by terrorist groups. After World War II, several cases of terror with biological weapons then occurred, for example, the case of the 1984 Rajneeshee religious cult, Aum Shinrikyo 1995, and anthrax terror in the United States in $2001 .^{27}$

\section{International Regulation on Combatting Bioterrorism}

The discussion of biological weapons has begun since the 1925 Geneva convention that explicitly addresses biological weapons. But this convention applies only to states' use in warfare, not to non-state actors or use in situations other than "warfare," such as during peacetime or internal conflicts. But after many years, it seems that the efforts to ban the use of biological weapons seem not really successful. Until now, several regulations regarding eradicating biological weapons have been formed, for example:

\section{a. The convention on the Prohibition of the Development, Production and Stockpiling of Bacteriological [Biological] and Toxin Weapons and Their Destruction 1972 (Biological Weapon Convention 1972)}

For nearly 50 years after the 1925 Geneva Protocol was signed, no additional international agreements were reached dealing with biological weapons. Many countries were developed and produced biological weapons during that time because the geneva protocol doesn't prohibit them. The Biological Weapon Convention was ratified in 1972 on the prohibition of developing, producing, stockpiling, possessing, or maintaining biological agents in amounts that could not be justified for prevention, self-protection, or other peaceful purposes. This convention is not an anti-terrorism convention as the convention does not specifically prohibit the use of biological weapons by non-state actors. Indeed, at that time, the state parties did not consider the possibility of bioterrorism when the BWC was conceived. ${ }^{28}$

But further in article 4, it is stated that "Each State Party to this Convention shall, following its constitutional processes, take any necessary measures to prohibit and prevent the development, production, stockpiling, acquisition, or retention of the agents, toxins, weapons, equipment, and means of delivery specified in Article I of the Convention, within the territory of such State, under its jurisdiction or its control anywhere". Each country is given the authority to make a regulation based on its jurisdiction to prohibit the use of bioweapons under its national law. However, due to unclear mechanisms in making national regulations, Only a few countries have taken administrative action or have enacted national legislation under this convention's provisions. ${ }^{29}$

\section{b. International Convention for the Suppression of Terrorist Bombings (Terrorist Bombing Convention) 1997}

The United Nations Convention on the Suppression of Terrorist Bombings, which entered into force in May 2001, will punish anyone who uses biological weapons by any state and a terrorist organization. The supporters of this convention want firm action to directly criminalize the illegal use, development, and possession of biological weapons by any party. ${ }^{30}$ The

\footnotetext{
${ }^{26}$ Ibid., 500.

${ }^{27}$ Ibid., 501.

${ }^{28}$ Eric Merriam, "THE INTERNATIONAL LEGAL REGIME AFFECTING BIOTERRORISM PREVENTION”, National Security Law Journal 3, no. 1 (2014): 1-46, 7.

29 Masahiko Asada, "SECURITY COUNCIL RESOLUTION 1540 TO COMBAT WMD TERRORISM: EFFECTIVENESS AND LEGITIMACY IN INTERNATIONAL LEGISLATION", Journal of Conflict \& Security Law 13, no. 3 (2008): 303-332, 306-307, DOI: 10.1093/jcs1/krp002.

${ }^{30}$ David P Fidler, "BIOTERRORISM, PUBLIC HEALTH, AND INTERNATIONAL LAW", Chicago Journal of International Law 3, no. 1 (2002): 7-26, 15.
} 
provision on the Terrorist Bombing Convention is addressing bioterrorism, that the convention will criminalize unlawful and illegal use of "explosive and another lethal device" in, into, or against the place of public use to cause death or serious bodily injury or likely to result in major economic loss. The meaning of 'explosive or other lethal devices' as written in article 1 paragraph 3 (a) and (b):

3) "Explosive or other lethal devices" means:

(a) A weapon or device that is designed to explode or incinerate and also has the capability to cause serious bodily injury, substantial material damage, or even death;

(b) A weapon or device designed to have the ability to disseminate chemical toxins, biological agents or radiation or radioactive material, or any other similar substances can cause serious bodily injury, substantial material damage, or even death to a human.

\section{c. International Convention For the Suppression of The Financing of Terrorism (1999)}

In carrying out an act of terrorism, funding is significant to sustain its operations. Furthermore, funding is also needed to promote an ideology, finance terrorist members and their families, fund travel and lodging, recruit and train new members, falsify identities and documents, purchase weapons, and design and carry out operations. Therefore efforts to tackle terrorism will not be successful without eradicating its funding activities. ${ }^{31}$

Considering that the funding of terrorism is a severe problem and could endangering the international community as a whole and how much the acts of terrorism depend on how much funding they get. Through this Convention, United Nations General Assembly called upon all states to take steps to counteract and prevent all form of the act to financing the terrorism activity through the appropriate domestic measures, whether the financing is direct or indirect through the organizations which claim that their activity is related to charitable, social or cultural goals or which are also engaged in unlawful activities such as drug dealing, racketeering and illicit arms trafficking, including the exploitation of persons for purposes of funding terrorist activities, and in particular to consider, where appropriate, adopting regulatory measures to prevent and counteract movements of funds suspected to be intended for terrorist purposes without impeding in any way the freedom of legitimate capital movements and to intensify the exchange of information concerning international movements of such funds. ${ }^{32}$

The financing of terrorism referred to in this convention covers all forms of terrorism and does not depend on one particular type of terrorism crime, including bioterrorism. Crime referred to in this convention is also a crime that can be extradited as long as the country has an agreement and agreed to do so. However, if it does not have a convention agreement, this can be used as a reference. If there are conflicting provisions in the convention, the state parties will consider resolving the problem between them.

\section{d. United Nation Security Council Resolution 1540 (2004)}

The United Nations Security Council Resolution 1540 of 2004 (in this study referred to as UNSCR 1540) is a binding international legal resource that outlined regulation concerning eradicating bioterrorism. This instrument was adopted after the $9 / 11$ tragedy as the urgency to prevent weapons from causing mass destruction acted by irresponsible parties (such as terrorist or threatening states). In eradicating bioterrorism, UNSCR 1540 is considered an effective instrument to preclude terrorists from performing their actions. The development of UNSCR 1540 in the scope of bioterrorism eradication includes: 1) UNSCR 1540 focusing more on non-

\footnotetext{
${ }^{31}$ Monika Suhayati, "UNDANG-UNDANG PENCEGAHAN DAN PEMBERANTASAN TINDAK PIDANA PENDANAAN TERORISME DARI PERSPEKTIF HAK ASASI MANUSIA”, Jurnal Negara Hukum 4, no. 2 (2013): 231-249, DOI: 10.22212/jnh.v4i2.206.

${ }^{32}$ The Preamble of International Convention For The Suppression Of the Financing of Terrorism.
} 
state actors (individual being); 2) UNSCR 1540 also apply to Biological Weapons Conventions (BWC) countries; 3) UNSCR 1540 mandated member states to take into account the prevention of bioterrorism under their jurisdiction, and 4) UNSCR 1540 becomes the initiator of "quasi compliance" body under limited verification and implementation roles. Also, each article in this instrument is considered essential in eradicating bioterrorism. Moreover, based on Article 7 of the United Nations Charter, UNSCR 1540 as one of the Security Council resolutions will effectively be binding all UN member states.

Compared to some existed conventions such as BWC and CWC (Chemical Weapon Convention), which only centralized its matter in non-state actors and terrorist organizations, the subject of UNSCR 1540 has begun to shift as mentioned from the first paragraph in UNSCR 1540:

1. Decides that all States shall refrain from providing any form of support to non-State actors that attempt to develop, acquire, manufacture, possess, transport, transfer or use nuclear, chemical, or biological weapons and their means of delivery;

2. Decides also that all States, following their national procedures, shall adopt and enforce appropriate, effective laws which prohibit any non-State actor from manufacturing, acquiring, possessing, develop, transport, transfer or use nuclear, chemical, or biological weapons and their means of delivery, in particular for terrorist purposes, as well as attempts to engage in any of the foregoing activities, participate in them as an accomplice, assist or finance them;

Another important element of UNSCR 1540 is that a security council resolution will be binding to all countries. Thus the state cannot ignore its legal obligations to eradicate bioterrorism, whether they agree or not to the provisions.

\section{e. Protocol to the Convention for the Suppression of Unlawful Acts Against the Safety of Maritime Navigation (2005 SUA Convention)}

The 2005 SUA Convention is the result of an amendment to the 1988 SUA Convention in response to the UN Security Council's increasing risk of international terrorism. The new 2005 SUA Convention has greater scope for violations of the use of nuclear, biological, and chemical weapons (CBRN) and other radioactive materials not contained in previous maritime instruments. The 2005 SUA Convention also regulates the prevention of CBRN weapons' transportation to reduce the possibility that the weapons will be used in acts of terrorism. This convention is also the first international convention on preventing and eradicating CBRN terrorism in the ocean. The 2005 SUA Convention was adopted when control of CBRN weapons came to the UN Security Council's attention during diplomatic conferences. The UN Security Council takes several actions relating to the risk of terrorism by using NUBIKA weapons, including UNSCR 1540 . The key features in this convention: ${ }^{33}$

(1) The 1998 SUA Convention outlined international cooperation working under the commission of unlawful acts concerning the safety of maritime navigation, as follows: the series of violent acts against a person who bears a threatening device which potentially will destroy or damage the ship, and the act of seizing the ship by force. Member states, hereby obliged to prosecute or extradite the offenders to pursue justice. Another instrument that contained similar provision is the 1988 Protocol for the Suppression of Unlawful Acts against the Safety of Fixed Platform Located on the Continental Shelf (1988 SUA Protocol), which regulate the prevention against the act relating to the safety of fixed platform lies on the continental shelf. The enactment of the 2005 SUA Convention of Unlawful Acts Against the Safety of Maritime Navigation aims to strengthen the previous protocol, namely the 1988 SUA Protocol, in its commitment to provide an

\footnotetext{
${ }^{33}$ United Nations Office on Drugs and Crime, "THE INTERNATIONAL LEGAL FRAMEWORK AGAINST CHEMICAL, BIOLOGICAL, RADIOLOGICAL AND NUCLEAR TERRORISM", Counter-Terrorism Legal Training Curriculum, (2016), 34.
} 
adequate response to prevent the risk to maritime navigation conducted by an international terrorist.

(2) The 2005 SUA convention regulates the use of a ship in preventing the act from causing serious damage or even death, the transfer of terrorism in evading the prosecution, and the unlawful transfer of weapons through maritime routes that potentially caused mass destruction.

The SUA Convention is considered one of the first initiators that regulate precisely the interdiction and prevention of biological weapons for such terrorist acts. However, this instrument solely regulates bioterrorism in ships and any acts that endanger maritime navigation.

\section{f. Convention on the Suppression of Unlawful Acts Relating to International Civil Aviation (2010 Beijing Convention)}

Shortly after the occurrence of the terrorist attack in the United States (9/11 Attack), the Council International Civil Aviation Organization (ICAO) ${ }^{34}$ Enacted A33-1 resolution, adopted in October 2001. The main point of this resolution aims to address existing or any advance threats to civil aviation, specifically in reviewing the sufficiency of present aviation conventions concerning preventing, eradicating, and combating any terrorism acts in civil aviation and reinforcing aviation security. The aforementioned resolution and supporting recommendation from the Ministerial High-Level Conference on Aviation Safety held in February 2002, therefore put into action by ICAO representatives' approval to review the present instrument of aviation security agenda. Moreover, the Beijing Convention has stipulated advance violations attached to CBRN weapons and radioactive substances, which was not contained in the previous convention regarding aviation instruments. ICAO resolution, therefore, become the first direct instrument that outlined the prevention and eradication of CBRN terrorism act in the aviation realm.

\section{Conclusion}

According to the explanation above, it shows that international instruments, unfortunately, have not regulated the eradication of bioterrorism thoroughly. However, about 6 (six) instruments outlined the prohibition of biological weapons utility for conducting a terrorist attack. These instruments, namely The Convention on the Prohibition of the Development, Production and Stockpiling of Bacteriological [Biological] and Toxin Weapons and on Their Destruction 1972 (Biological Weapon Convention 1972); International Convention for the Suppression of Terrorist Bombings (Terrorist Bombing Convention) 1997; International Convention For the Suppression of The Financing of Terrorism (1999); United Nations Security Council Resolution 1540 (2004); Protocol to the Convention for the Suppression of Unlawful Acts Against the Safety of Maritime Navigation (2005 SUA Convention); Convention on the Suppression of Unlawful Acts Relating to International Civil Aviation (2010 Beijing Convention). However, these existing instruments are deemed insufficient to combat the concerning issue of bioterrorism. To date, there has been no specific convention that regulates the issue of bioterrorism comprehensively. Therefore, as the peacekeeper of states, the United Nations (UN) shall immediately establish stronger regulations to eradicate terrorism in any manner and prevent relating acts to protect the world's security.

\section{A. Journal and Article}

\section{References}

\footnotetext{
${ }^{34}$ ICAO is a special UN agency; states established it in 1944 to manage the International Civil Aviation Convention (Chicago Convention). ICAO has 193 state parties. Accessed from https://www.icao.int/abouticao/Pages/default.aspx on April 28, 2020, at 19:23.
} 
Asada, Masahiko. "SECURITY COUNCIL RESOLUTION 1540 TO COMBAT WMD TERRORISM: EFFECTIVENESS AND LEGITIMACY IN INTERNATIONAL LEGISLATION", Journal of Conflict \& Security Law 13, no. 3, 2008: 303-332, DOI: $10.1093 / \mathrm{jcsl} / \mathrm{krp002}$.

Aziz, Isna Rasdianah., Saputra, Andika. "BIOTERRORISM: THE ROLE OF GENETICS AND MOLECULAR BIOLOGY”, Prosiding Seminar Nasional Biology for Life 3, no. 1, 2017: 63-69, 63, DOI: 10.24252/PSB.v3i1.5587.

Barras, V., G. Greub. "HISTORY OF BIOLOGICAL WARFARE AND BIOTERRORISM", Journal of Clinical and Microbiology Infection 20, no. 06, 2014: 497-502, DOI: 10.1111/1469-0691.12706.

Besides, Revaz. "WEAPONS OF MASS DESTRUCTION AND INTERNATIONAL TERRORISM", Georgia: Final Project Report, 2007: 1-36

Carus, W. Seth. "A CENTURY OF BIOLOGICAL-WEAPONS PROGRAMS (1915-2015): REVIEWING THE EVIDENCE", The Nonproliferation Review Special Section: Nuclear Asia 24, no. 1-2, 2017: 129-153, DOI: 10.1080/10736700.2017.1385765.

Carus, W. Seth. "THE THREAT OF BIOTERRORISM", National Defense University Institute for National Strategic Studies 127, 1997: 1-4.

Dagen, Heather A. "BIOTERRORISM: PERFECTLY LEGAL", Catholic University Law Review 49, no. 2, 2002: 535-573.

Fidler, David P. "BIOTERRORISM, PUBLIC HEALTH, AND INTERNATIONAL LAW", Chicago Journal of International Law 3, no. 1, 2002: 7-26.

Fiedler, Beth Ann., Nikolaenko, Dmitry. "INVESTIGATING COVID-19: RECURRING METHODOLOGICAL PROBLEMS IN THE STUDY OF INFECTIOUS DISEASE", Environmental Epidemiology 14, no. 2 (2020): 4-12.

Funk, Cameron. "AMERICA'S STATE OF READINESS AGAINST BIOTERRORISM", Pepperdine Policy Review 10, no. 1, 2018: 1-20.

Goril, Saira., Tomar, Anjani Singh. "BIOTERRORISM \& BIODEFENSE: AN ENVIRONMENTAL AND PUBLIC HEALTH PREPAREDNESS", Rupkatha Journal on Interdisciplinary Studies in Humanities 12, no. 1, 2020: 1-15, DOI: 10.21659/rupkatha.v12n2.13.

Janik, Edyta. et al. "BIOLOGICAL TOXINS AS THE POTENTIAL TOOLS FOR BIOTERRORISM", International Journal of Molecular Science 20, no. 5, 2019: 1181, DOI: 10.3390/ijms20051181.

Merriam, Eric. "THE INTERNATIONAL LEGAL REGIME AFFECTING BIOTERRORISM PREVENTION", National Security Law Journal 3, no. 1, 2014: 1-46.

Pal, Mahendra. et al., "AN OVERVIEW ON BIOLOGICAL WEAPONS AND BIOTERRORISM", American Journal of Biomedical Research 5, no. 2, 2017: 24-34, DOI: 10.12691/ajbr-5-2-2.

Sharma, Divashree. et al., "BIOTERRORISM: LAW ENFORCEMENT, PUBLIC HEALTH \& ROLE OF ORAL AND MAXILLOFACIAL SURGEON IN EMERGENCY PREPAREDNESS", Journal of Oral and Maxillofacial Surgery 15, no. 2, 2016: 137143, DOI: 10.1007/s12663-015-0834-X.

Suhayati, Monika. "UNDANG-UNDANG PENCEGAHAN DAN PEMBERANTASAN TINDAK PIDANA PENDANAAN TERORISME DARI PERSPEKTIF HAK ASASI MANUSIA", Jurnal Negara Hukum 4, no. 2, 2013: 231-249, DOI: 10.22212/jnh.v4i2.206.

United Nations Office on Drugs and Crime, "THE INTERNATIONAL LEGAL FRAMEWORK AGAINST CHEMICAL, BIOLOGICAL, RADIOLOGICAL AND NUCLEAR TERRORISM", Counter-Terrorism Legal Training Curriculum, 2016. 
Yakubu, Dennis D., Paul, Daniel A. "BIOLOGICAL WEAPONS A GLOBAL THREAT: A SUSTAINABLE APPROACH FOR EARLY IDENTIFICATION", African Journal of Environment and Natural Science Research 2, no. 2, 2019: 6-11

\section{B. Book}

Clutterbuck, Richard. Terrorism in an Unstable World. London: Routledge, 2006.

Farida, Nur. Me And Global Environment. Jakarta: Grasindo, 2009.

Gottfried, Robert S. The Black Death: Natural And Human Disaster In Medieval Europe. New York: The Free Press, 1985.

Hikam, Muhammad A.S. Deradikalisasi: Peran Masyarakat Sipil Indonesia Membendung Radikalisme. Jakarta: Kompas Media Nusantara, 2016.

Michael, George. Lone Wolf Terror and the Rise of Leaderless Resistance. Nashville: Venderbilt University Press, 2012.

S, Adjie. Terorisme. Jakarta: Pustaka Sinar Harapan, 2005.

\section{Internet}

https://www.nytimes.com/1972/01/19/archives/2-youths-charged-with-plot-to-poison-waterof-chicago.html accessed on December 16, 2019.

https://independensi.com/2020/03/24/covid-19-perang-biologi-berlakukan-darurat-militer/ accessed on March 27, 2020. 
$\underline{ }$ 